\title{
Gaya Humor terhadap Optimisme Mahasiswa yang Sedang Menyelesaikan Skripsi
}

\author{
Andi Muskerina, Kurniati Zainuddin', Ahmad Ridfah ${ }^{3}$ \\ 1.2Fakultas Psikologi Universitas Negeri Makassar; Jl. AP Pettarani \\ Makassar,(0411)845120/(0411)880784

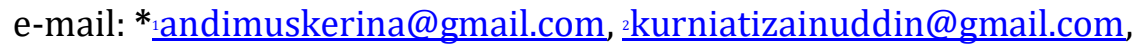 \\ sahmad.ridfah@unm.ac.id
}

\begin{abstract}
The collage students who accomplish the undergraduate thesis will face many demands and obstacles and lead them to some difficulties if they perform low optimism. The aim of this study was measuring the relationship between humor style and optimism among the Engineering students at State University of Makassar who accomplish the undergraduate thesis. The participants of this study were 231 collage students from Engineering Faculty at State University of Makassar. Sampling technique used in this study was accidental sampling with quantitative method. The result of this study showed that affiliative humor style positively related to optimism $(r=0,314, p=0,000)$, self enhancing humor positively related to optimism $(r=0,155, p=0,018)$, aggressive humor negatively correlated with optimism $(r=-0,324, p=0,000)$, and self-defeating humor negatively correlated with optimism $(r=-0,163, p=0,013)$. This study proved that affiliative humor and self-enhancing humor can increase the optimism. In contrast, aggressive and self-defeating humor can diminish the optimism among the students.
\end{abstract}

Keywords: Humor Style, Optimism, Student

Abstrak. Mahasiswa yang sedang skripsi akan menghadapi banyak tuntutan dan hambatan yang menyebabkan mereka sulit untuk menyelesaikan masa studi apabila tingkat optimisme rendah. Tujuan dari penelitian ini adalah untuk mengetahui hubungan antara gaya humor dengan optimisme pada mahasiswa Fakultas Teknik Universitas Negeri Makassar yang sedang skripsi. Subjek dalam penelitian ini berjumlah 231 orang mahasiswa Fakultas Teknik Universitas Negeri Makassar yang sedang skripsi. Teknik pengambilan sampel dalam penelitan ini adalah accidental sampling dengan metode penelitian kuantitatif. Hasil penelitian ini menunjukkan bahwa bentuk gaya humor affiliative memiliki hubungan positif yang sangat signifikan dengan optimisme $(r=0,314, p=0,000)$, selfenhancing humor memiliki hubungan positif yang signifikan dengan optimisme $(r=0,155, p=0,018)$, aggressive humor memiliki hubungan negatif yang sangat signifikan dengan optimisme $(r=-0,324, p=0,000)$, dan self-defeating humor memiliki hubungan negatif yang signifikan dengan optimisme $(r=-0,163, p=0,013)$. Penelitian ini dapat menjadi masukan bahwa affiliative humor dan self-enhancing humor dapat meningkatkan optimisme sedangkan aggressive humor dan self-defeating humor dapat menurunkan optimisme pada mahasiswa yang sedang skripsi.

Kata kunci: Gaya Humor, Mahasiswa, Optimisme 


\section{Pendahuluan}

Skripsi dianggap oleh sebagian mahasiswa sebagai tugas yang sulit, menghambat kelulusan, dan mempunyai banyak tuntutan yang harus dikerjakan, sehingga mahasiswa merasa kurang semangat dalam mengerjakan segala sesuatu yang berhubungan dengan skripsi. Mahasiswa dituntut pula untuk menyesuaikan diri dalam proses belajar pada proses penyusunan skripsi. Masalah-masalah yang dialami mahasiswa dapat memberikan penilaian terhadap kemampuan dirinya untuk mengerjakan skripsi menjadi rendah, dan penilaian subjek terhadap skripsi sebagai hal yang berat dan sulit dilakukan menjadi cukup tinggi. Hal penting yang dimiliki individu dan dapat menjadi solusi yang baik untuk masalah-masalah yang dihadapi mahasiswa yang sedang skripsi ialah optimisme.

Hasil pembagian angket yang dilakukan peneliti pada bulan September 2017 terhadap 63 mahasiswa dengan jumlah 7 mahasiswa pada setiap Fakultas yang sedang mengerjakan skripsi di Universitas Negeri Makassar ditemukan bahwa tingkat optimisme yang rendah banyak dialami oleh mahasiswa yang sedang skripsi. Satu Fakultas dengan mahasiswa yang tergolong optimisme rendah adalah Fakultas Teknik dengan persentase 71 \%. Berdasarkan hasil wawancara yang dilakukan peneliti pada bulan September 2017 terhadap 11 mahasiswa Fakultas Teknik yang sedang skripsi di Universitas Negeri Makassar, diperoleh hasil bahwa 9 dari mahasiswa yang menjadi subjek penelitian menyatakan sering mengalami optimisme yang rendah saat menyusun skripsi. Optimisme rendah yang dirasakan subjek, membuatnya menganggap kejadian-kejadian buruk adalah kesalahan diri sendiri, malas, motivasi kurang (rendah), mudah menyerah dan putus asa, prokrastinasi, dan menganggap tema penelitian kurang menarik. Tanggapan subjek sesuai dengan hasil penelitian yang dilakukan Anhar (2017) menyatakan bahwa sebagian

besar mahasiswa yang sedang menyusun skripsi memiliki tingkat optimisme yang tinggi jika mahasiswa memiliki keyakinan akan kemampuan diri, tidak mudah putus asa, dan akan memanfaatkan berbagai cara dalam menghadapi kendala-kendala ketika menyusun skripsi.

Chusniah dan Pitaloka (2012) mengemukakan bahwa optimisme terbukti memengaruhi kesejahteraan fisik dan psikologis, sehingga membuat perasaan nyaman akan diri sendiri, penerimaan diri, dan pertumbuhan. Yolanda (2016) dalam penelitiannya menyatakan bahwa terdapat 30 subjek yang memiliki tingkat optimisme yang tinggi, 12 subjek yang memiliki tingkat optimisme sedang, dan tidak ada subjek yang memiliki optimisme yang rendah. Hasil dalam penelitian ini memperlihatkan bahwa sebagian besar mahasiswa strata 1 di Kota Makassar memiliki tingkat optimisme yang tinggi dalam menjalani kehidupannya. 
Philanthrophy Journal of Psychology

Vol 2 Nomor 1 (2018), 57-70

ISSN 2580-6076 (Print), ISSN 2580-8532 (Online)

Matsumoto (2009) menjelaskan bahwa mahasiswa yang memiliki tingkat optimisme tinggi mengharapkan hasil yang terbaik dan akan berpikir positif dalam menghadapi situasi tertentu yakni untuk menyelesaikan skripsi. Individu dengan emosi positif akan mudah menyampaikan keadaan emosionalnya pada individu lain melalui humor. Hasil penelitian yang dilakukan Yue, Hao, dan Goldman (2010) menemukan bahwa penilaian individu terhadap suatu keadaan buruk yang dialami bisa berubah menjadi lebih positif jika strategi humor yang individu gunakan tepat. Penggunaan humor tidak terlepas dari gaya humor yang dimiliki individu dalam menyelesaikan masalah dilingkungan sosialnya. Chen dan Martin (2007a \& 2007b) dalam penelitiannya menunjukkan bahwa humor dapat menjadi salah satu cara untuk mengatasi kesulitan individu dan membuat individu memiliki kemampuan dalam menilai suatu keadaan lebih positif.

Martin dan Leftcourt (1984) mendefinisikan humor sebagai frekuensi senyum dan tawa individu, serta dapat menampilkan hiburan dalam berbagai situasi. Suatu humor tertentu dapat diterima oleh orang lain tergantung cara individu menerima sistem sosial yang ada. Humor bisa dinilai lucu bagi kelompok individu tertentu dan dalam situasi tertentu, namun tidak oleh kelompok yang lain atau dalam situasi berbeda. Hasil penelitian lain yang dilakukan oleh Yue, dkk (2010) pada 800 mahasiswa di Cina daratan dan Hong Kong menunjukkan bahwa affiliative humor dan self-enhancing humor yang beguna bagi indvidu untuk mengatasi masalah dan dapat meningkatkan optimisme dalam situasi sosial. Bentuk humor lain yaitu aggressive humor dan self-defeating humor berkorelasi negatif dengan optimisme. Mahasiswa di Cina daratan yang dianggap lebih kolektivis daripada mahasiswa Hong Kong dalam menggunakan strategi affiliative humor dan self-enhanching humor untuk meningkatkan optimisme dirinya. Aggressive humor dan self-defeating humor pada mahasiswa di Cina daratan dan Hong Kong dapat menurunkan optimisme individu. Mahasiswa yang memiliki affiliative humor dan self-enhancing humor yang tinggi cenderung meningkatkan optimisme yang memiliki peran penting dalam menentukan dan menggambarkan kemampuan diri individu, memengaruhi kesehatan fisik dan mental individu, mempertahankan motivasi individu ketika mengalami kesulitan, serta meningkatkan hubungan sosial dengan individu lain. Mahasiswa yang memiliki aggressive humor dan self-defeating humor yang tinggi dapat menurunkan tingkat optimisme individu. Mahasiswa cenderung menyakiti orang lain, menurunkan harga diri orang lain, dan menyangkal kondisi yang tidak sesuai dengan yang sebenarnya.

Adapun tujuan dalam penelitian ini adalah untuk mengetahui ada hubungan antara affiliative humor terhadap optimisme pada mahasiswa yang sedang skripsi, ada hubungan antara self-enhancing humor terhadap optimisme pada mahasiswa yang sedang skripsi, ada 
Philanthrophy Journal of Psychology

Vol 2 Nomor 1 (2018), 57-70

ISSN 2580-6076 (Print), ISSN 2580-8532 (Online)

hubungan antara aggresive humor terhadap optimisme pada mahasiswa yang sedang skripsi, dan ada hubungan antara self-defeating humor terhadap optimisme pada mahasiswa yang sedang skripsi. Hasil penelitian ini, diharapkan dapat digunakan dalam pengembangan ilmu psikologi khususnya psikologi kepribadian, psikologi positif, psikologi pendidikan dan psikologi sosial. Penelitian ini diharapkan dapat memberikan referensi bagi individu yang sedang skripsi agar dapat mengatasi optimisme yang rendah dalam menyelesaikan skripsi dan memberikan pengetahuan tentang sesuatu yang positif dari gaya humor serta diharapkan mampu menjadi tambahan referensi bagi peneliti selanjutnya yang tertarik meneliti tentang variabel yang sama.

Seligman (2006) mengemukakan bahwa optimisme merupakan cara pandang individu secara menyeluruh, positif, dan bermakna bagi dirinya terhadap segala sesuatu. Seligman (2006) mengemukakan bahwa optimisme terdiri dari tiga aspek, yaitu permanensi, pervasivitas, dan personalisasi. Permanensi merupakan gaya penjelasan mengenai cara pandang individu dalam menyikapi peristiwa yang berkaitan dengan waktu, yaitu sementara dan menetap. Pervasivitas merupakan gaya penjelasan yang berkaitan dengan cara pandang individu mengenai dua dimensi ruang lingkup suatu peristiwa, yaitu universal dan spesifik. Personalisasi merupakan gaya penjelasan yang dimiliki individu berkaitan dengan pemahaman mengenai sumber penyebab suatu peristiwa yang bersifat internal dan ekternal. Seligman (2006) mengemukakan bahwa optimisme dipengaruhi oleh gaya humor yang dapat mengatasi menurunnya optimisme pada diri individu, sehingga kesehatan psikologis individu menjadi lebih baik dengan unsur lungkungan, konsep diri, pekerjaan, dan pendidikan.

Sowmya, Nizamudeen, dan Magesh (2015) mengemukakan bahwa humor melibatkan segala rentan usia dan latar belakang sosialnya, namun cara untuk menunjukkan dan menggunakan humor dapat berbeda dari masing-masing individu. Martin (2004) menjelaskan bahwa gaya humor ialah cara individu menggunakan humor dalam hubungan interpersonal dan sosialnya. Martin, Puhlik-Doris, Larsen, Gray, dan Weir (2003) mengemukakan empat bentuk gaya humor, yaitu Affiliative humor mengacu pada kecenderungan individu mengatakan, menceritakan, dan melakukan hal-hal lucu dan spontan untuk menghibur orang lain, memfasilitasi hubungan, dan mengurangi ketegangan antar pribadi. Self-enhancing humor mengacu pada kecenderungan individu merasa geli dan menertawakan peristiwa yang berbeda dalam hidup serta mempertahankan perspektif dalam menghadapi masalah. Aggressive humor mengacu pada penggunaan humor yang berupa cemooh, sarkasme, mengejek, dan penghinaan atau pencelaan. Self-defeating humor 
yakni penggunaan humor yang berkaitan dengan meremehkan atau merendahkan diri sendiri.

Individu dalam proses menyelesaian studi membutuhkan keterampilan untuk menghilangkan dan menghindarkan diri dari optimisme yang rendah. Cerver, Scheier, dan Segestrom (2010) mengemukakan bahwa inidvidu membutuhkan motivasi dalam proses mencapai tujuan yang diinginkan karena dapat mempengaruhi optimisme yang dimiliki individu tersebut. Tingkatan optimisme dapat dibentuk dengan penggunaan humor dalam berinteraksi dan mengomunikasikan gagasan yang dimiliki untuk mencapai tujuan. Humor yang digunakan ketika berkomunikasi tidak terlepas dari bentuk atau gaya humor. Gaya humor menurut Martin (2004) adalah kecenderungan individu untuk menunjukkan rasa humor pada situasi tertentu yang membentuk karakter individu. Martin, Puhlik-Doris, Larsen, Gray, dan Weir (2003) mengemukakan bahwa gaya humor dapat berupa lelucon yang bersifat spontan, menceritakan dan mengatakan hal-hal lucu, mempertahankan perspektif lucu meski dalam kesulitan, humor yang bersifat sarkasme, mengatakan hingga menghina sesuatu yang ada pada dirinya.

Hipotesis yang diajukan oleh peneliti adalah ada hubungan positif antara tingkat optimisme dengan affiliative humor, ada hubungan positif antara tingkat optimisme dengan self-enhancing humor, ada hubungan negatif antara tingkat optimisme dengan aggressive humor, dan ada hubungan negatif antara tingkat optimisme dengan self-defeating humor.

\section{Metode}

Variabel terikat dalam penelitian ini adalah optimisme dan variebel bebasnya adalah gaya humor. Sampel penelitian ini sebesar 231 mahasiswa yang sedang skripsi diperoleh dengan menggunakan teknik pengambilan sampel accidental sampling. Skala optimisme diadaptasi dari Yolanda (2016) yang melakukan proses validasi melalui professional judgement diperoleh nilai $V$ untuk 29 aitem bergerak dari 0,5 sampai dengan 1 yang membuktikan tingkat validasi tergolong baik. Validitas skala gaya humor yang diperoleh dalam penelitian yang dilakukan Nuzqia (2016) setelah melakukan proses melalui professional judgement menggunakan rumus Aiken's $V$ diperoleh koefisien validitas terkecil 0,750 dan koefisien validitas terbesar 0,813 yang membuktikan bahwa tingkat validasi tergolong baik.

Validitas faktorial menggunakan Confirmatory Factor Analysis (CFA) yang dilakukan dalam penelitian ini menggunakan aplikasi statcal versi 1.1. Hasil olah data CFA pada skala optimisme memperoleh nilai yang lebih atau sama dengan range antara 0,5-0,76, sehingga 
11 aitem dinyatakan valid. Skala gaya humor yang memperoleh nilai CFA lebih dari atau sama dengan range 0,5-0,78, sehingga 16 aitem dinyatakan valid.

Reliabilitas untuk skala optimisme yang diperoleh dalam penelitian yang dilakukan setelah uji coba dengan 21 aitem dan melibatkan 358 subjek diperoleh nilai alpha sebesar 0,831. Nilai tersebut masuk dalam kategori reliabilitas yang bagus. Reliabilitas untuk skala gaya humor yang diperoleh dalam penelitian yang dilakukan setelah uji coba dengan 30 aitem dan melibakan 434 subjek masing-masing berjumlah 7 aitem pada affiliative humor dan self-enhancing humor dan 8 aitem pada aggressive humor dan self-defeating humor. Affiliative humor sebesar 0,732 yang termasuk dalam kategori cukup bagus. Self-enhancing memeroleh nilai sebesar 0,753 yang termasuk dalam kategori cukup bagus. Agressive humor memeroleh nilai yaitu sebesar 0,739 yang termasuk dalam kategori cukup bagus. Selfdefeating humor memeroleh nilai sebesar 0,853 yang termasuk dalam kategori bagus.

Analisis hipotesis pada penelitian ini menggunakan Spearman's Rho. Peneliti membagi tiga kategorisasi untuk skala gaya humor yaitu kategori tinggi, sedang, dan rendah, sedangkan untuk skala optimisme hanya membagi skor subjek kedalam dua ketegorisasi, yaitu kategori tinggi dan rendah.

\section{H a s i l}

Tabel 1.

Deskripsi Data Penelitian

\begin{tabular}{ccccc}
\hline \multirow{2}{*}{ Variabel } & \multicolumn{4}{c}{ Empirik } \\
\cline { 2 - 5 } & Min & Max & Mean & SD \\
\hline Affiliatif humor & 12 & 20 & 17,48 & 2,014 \\
Self-enhancing humor & 9 & 20 & 16,06 & 2,304 \\
Aggressive humor & 14 & 19 & 16,00 & 1,673 \\
Self-defeating & 13 & 18 & 15,67 & 1,936 \\
Optimisme & 15 & 55 & 41,90 & 6,860 \\
\hline
\end{tabular}

Tabel 2.

Kategorisasi affiliative humor

\begin{tabular}{cccc}
\hline Interval & Frekuensi & Persentase (\%) & Kategori \\
\hline $19,49 \leq \mathrm{X}$ & 21 & 20,59 & Tinggi \\
$15,47<\mathrm{X}<19,49$ & 65 & 63,72 & Sedang \\
$\mathrm{X} \leq 15,47$ & 16 & 15,69 & Rendah \\
\hline Jumlah & $\mathbf{1 0 2}$ & $\mathbf{1 0 0 \%}$ & \\
\hline
\end{tabular}

Hasil persentase menunjukkan bahwa mahasiswa yang sedang skripsi yang menjadi sampel penelitian memiliki rata-rata tingkat affiliative humor yang sedang. Tabel 3.

Kategorisasi self-enhancing humor

\begin{tabular}{cccc}
\hline Interval & Frekuensi & Persentasi $(\%)$ & Kategori \\
\hline $18,36 \leq \mathrm{X}$ & 4 & 12,12 & Tinggi \\
$13,75<\mathrm{X}<18,36$ & 27 & 81,82 & Sedang
\end{tabular}


Philanthrophy Journal of Psychology

Vol 2 Nomor 1 (2018), 57-70

ISSN 2580-6076 (Print), ISSN 2580-8532 (Online)

\begin{tabular}{cccc}
$\mathrm{X} \leq 13,75$ & 2 & 6,06 & Rendah \\
\hline Jumlah & $\mathbf{3 3}$ & $\mathbf{1 0 0 \%}$ & \\
\hline
\end{tabular}

Hasil persentase menunjukkan bahwa mahasiswa yang sedang skripsi yang menjadi sampel penelitian memiliki rata-rata tingkat self-enhancing yang sedang.

Tabel 4.

Kategorisasi aggressive humor

\begin{tabular}{cccc}
\hline Interval & Frekuensi & Persentase (\%) & Kategori \\
\hline $17,67 \leq \mathrm{X}$ & 2 & 18,18 & Tinggi \\
$14,33<\mathrm{X}<17,67$ & 9 & 81,82 & Sedang \\
$\mathrm{X} \leq 14,33$ & 0 & 0 & Rendah \\
\hline Jumlah & $\mathbf{1 1}$ & $\mathbf{1 0 0 \%}$ & \\
\hline
\end{tabular}

Hasil persentase menunjukkan bahwa mahasiswa yang sedang skripsi yang menjadi sampel penelitian memiliki rata-rata tingkat aggressive humor yang sedang.

Tabel 5.

Kategorisasi self-defeating humor

\begin{tabular}{cccc}
\hline Interval & Frekuensi & Persentase (\%) & Kategori \\
\hline $17,61 \leq X$ & 3 & 33,33 & Tinggi \\
$13,73<X<17,61$ & 6 & 66,67 & Sedang \\
$X \leq 13,73$ & 0 & 0 & Rendah \\
\hline Jumlah & $\mathbf{9}$ & $\mathbf{1 0 0 \%}$ & \\
\hline
\end{tabular}

Hasil persentase menunjukkan bahwa mahasiswa yang sedang skripsi yang menjadi sampel penelitian memiliki rata-rata tingkat self-defeating humor yang sedang.

Tabel 6.

Kategorisasi Skor Optimisme

\begin{tabular}{cccc}
\hline Interval & Frekuensi & Persentase (\%) & Kategori \\
\hline $41,90 \leq \mathrm{X}$ & 91 & 58,71 & Tinggi \\
$\mathrm{X} \leq 41,90$ & 64 & 41,29 & Rendah \\
\hline Jumlah & $\mathbf{1 5 5}$ & $\mathbf{1 0 0 \%}$ & \\
\hline
\end{tabular}

Hasil persentase menunjukkan bahwa mahasiswa yang sedang skripsi yang menjadi sampel penelitian memiliki rata-rata optimisme yang tinggi.

Tabel 7.

Hasil uji hipotesis affiliative humor terhadap optimisme pada mahasiswa yang sedang skripsi

\begin{tabular}{cccc}
\hline Variabel & $\boldsymbol{r}$ & $\boldsymbol{p}$ & Keterangan \\
\hline $\begin{array}{c}\text { Affiliative humor } \\
\text { Optimisme }\end{array}$ & 0,424 & 0,000 & Sangat Signifikan \\
\hline
\end{tabular}

Hasil uji hipotesis menyatakan bahwa terdapat hubungan positif yang sangat signifikan antara affiliative humor terhadap optimisme mahasiswa yang sedang skripsi dan memiliki hubungan yang di kategorikan sedang karena nilai korelasi berkisar antara 0,40- 
Philanthrophy Journal of Psychology

Vol 2 Nomor 1 (2018), 57-70

ISSN 2580-6076 (Print), ISSN 2580-8532 (Online)

0,599, sehingga nilai mendekati 1 dan 0 maka hubungan antara variabel tidak lemah dan tidak kuat.

Tabel 8.

Hasil uji hipotesis self-enhancing humor terhadap optimisme pada mahasiswa yang sedang skripsi

\begin{tabular}{cccc} 
Variabel & $\boldsymbol{r}$ & $\boldsymbol{p}$ & Keterangan \\
\hline $\begin{array}{c}\text { Self- enhancing humor } \\
\text { Optimisme }\end{array}$ & 0,235 & 0,003 & $\begin{array}{c}\text { Sangat } \\
\text { Signifikan }\end{array}$ \\
\hline
\end{tabular}

Hasil uji hipotesis menyatakan bahwa terdapat hubungan positif yang sangat signifikan antara self-enhancing humor terhadap optimisme mahasiswa yang sedang skripsi dan memiliki hubungan yang di kategorikan rendah karena nilai korelasi berkisar antara 0,20-0,399 dengan nilai yang mendekati 0 berarti hubungan antar variabel lemah. Tabel 9.

Hasil uji hipotesis aggressive humor terhadap optimisme pada mahasiswa yang sedang skripsi

\begin{tabular}{cccc}
\hline Variabel & $\boldsymbol{r}$ & $\boldsymbol{p}$ & Keterangan \\
\hline $\begin{array}{c}\text { Aggressive humor } \\
\text { Optimisme }\end{array}$ & $-0,374$ & 0,000 & $\begin{array}{c}\text { Sangat } \\
\text { Signifikan }\end{array}$ \\
\hline
\end{tabular}

Hasil uji hipotesis menyatakan bahwa ada hubungan negatif yang sangat signifikan antara aggressive humor terhadap optimisme mahasiswa yang sedang skripsi dan memiliki hubungan yang di kategorikan rendah karena nilai korelasi berkisar antara 0,20-0,399 dengan nilai mendekati 0 yang dapat diartikan bahwa hubungan antar variabel lemah.

Tabel 10.

Hasil uji hipotesis self-defeating humor terhadap optimisme pada mahasiswa yang sedang skripsi

\begin{tabular}{cccc}
\hline Variabel & $\boldsymbol{r}$ & $\boldsymbol{p}$ & Keterangan \\
\hline $\begin{array}{c}\text { Self-defeating humor } \\
\text { Optimisme }\end{array}$ & $-0,374$ & 0,002 & $\begin{array}{c}\text { Sangat } \\
\text { Signifikan }\end{array}$ \\
\hline
\end{tabular}

Hasil uji hipotesis menunjukkan bahwa ada hubungan negatif yang sangat signifikan antara self-defeating humor terhadap optimisme mahasiswa yang sedang skripsi dan memiliki hubungan yang di kategorikan rendah karena nilai korelasi berada antara nilai koefisien 0,20-0,399 dengan nilai yang mendekati 0 maka diartikan bahwa hubungan antar variabel lemah.

\section{Diskusi}

Affiliative humor pada hasil penelitian menunjukkan bahwa 55 subjek memiliki skor diatas nilai mean dan sebanyak 47 subjek memiliki skor dibawah nilai mean. Martin, Doris, Larsen, Gray, dan Weir (2003) mengemukakan bahwa individu dengan gaya humor 
Philanthrophy Journal of Psychology

Vol 2 Nomor 1 (2018), 57-70

ISSN 2580-6076 (Print), ISSN 2580-8532 (Online)

affiliative humor cenderung mengatakan, menceritakan, dan melakukan hal-hal lucu dan spontan untuk menghibur orang lain, memfasilitasi hubungan, dan mengurangi ketegangan antarpribadi. Individu yang mempunyai skor diatas nilai mean menujukkan bahwa individu banyak terlibat dalam lelucon dalam berinteraksi di lingkungan sosialnya.

Self-enhancing humor pada hasil penelitian menunjukkan bahwa 13 subjek mempunyai skor diatas nilai mean dan sebanyak 20 subjek mempunyai skor dibawah nilai mean. Martin, Doris, Larsen, Gray, dan Weir (2003) mengemukakan bahwa individu yang memiliki gaya humor self-enhancing cenderung merasageli dan menertawakan peristiwa yang berbeda dalam hidup serta mempertahankan perspektif dalam menghadapi masalah. Teori yang dikemukakan oleh Martin, Doris, Larsen, Gray, dan Weir (2003) menunjukkan bahwa subjek dalam penelitian ini tidak mampu menghibur diri dalam menghadapi masalah dan tidak merasa terbebas dari kecemasan atau rasa tertekan karena mempunyai skor tinggi dibawah nilai mean.

Aggressive humor pada hasil penelitian menunjukkan bahwa sebanyak 4 subjek mempunyai skor diatas nilai mean dan sebanyak 5 subjek mempunyai skor dibawahnilai mean. Martin, Doris, Larsen, Gray, dan Weir (2003) mengemukakan bahwa individu yang memiliki aggressive humor berkaitan dengan penggunaan humor yang berupa cemooh, sarkasme, mengejek, dan penghinaan atau pencelaan. Berdasarkan skor dibawah nilai mean yang dikategorikan tinggi dapat menunjukkan bahwa subjek dalam penelitian ini mengekspresikan humor dengan tidak mempertimbangkan akibat yang muncul pada individu lain.

Self-defeating humor pada hasil penelitian menunjukkan bahwa sebanyak 7 subjek mempunyai skor lebih dari atau sama dengan nilai mean dan sebanyak 4 subjek mempunyai skor dibawah nilai mean. Martin, Doris, Larsen, Gray, dan Weir (2003) mengemukakan bahwa individu yang memiliki self-defeating humor berkaitan dengan penggunaan humor yang berkaitan dengan meremehkan atau merendahkan diri sendiri. Sesuai teori yang dikemukakan oleh Martin, Doris, Larsen, Gray, dan Weir (2003) menunjukkan bahwa subjek dalam penelitian ini mendekatkan diri dengan individu lain dengan tidak ingin kehilangan wibawa dan tidak merugikan diri sendiri.

Hasil analisis deskriptif menunjukkan bahwa skor rata-rata yang ditunjukkan oleh individu yang sedang skripsi pada skala gaya humor menunjukkan gaya humor berada pada kategori sedang. Sowmya, Nizamudeen, Magesh (2015) mengemukakan bahwa humor melibatkan segala rentan usia dan latar belakang sosialnya, namun cara untuk menunjukkan dan menggunakan humor dapat berbeda dari masing-masing individu. Gaya humor sedikit berbeda setiap digunakan pada situasi tertentu, namun gaya humor yang digunakan 
Philanthrophy Journal of Psychology

Vol 2 Nomor 1 (2018), 57-70

ISSN 2580-6076 (Print), ISSN 2580-8532 (Online)

tersebut cenderung menjadikan individu menjadi berkarakter dan dinilai cukup konsisten penggunaannya dari waktu ke waktu. Sesuai dengan teori tersebut bahwa semua subjek dalam penelitian ini menunjukkan bahwa subjek mempunyai gaya humor yang lebih dominan dalam diri individu. Mahasiswa 102 orang dari 155 mahasiswa yang menjadi subjek penelitian ini yang lebih dominan pada bentuk affiliative humor.

Hasil analisis deskriptif menunjukkan bahwa skor rata-rata yang ditunjukkan oleh mahasiswa yang sedang skripsi pada skala optimisme berada padakategori tinggi. Stereotip yang ada mengemukakan bahwa optimisme rendah rentan dialami oleh mahasiswa yang sedang skripsi. Optimisme rendah dapat muncul pada individu yang kesulitan dalam menyelesaikan masalah yang berkaitan dengan skripsi yang sedang dikerjakan. Seligman (2006) mengemukakan bahwa lingkungan yang menjadi faktor yang berpotensi meningkatkan optimisme individu. Individu yang memiliki optimisme mampu menghasilkan sesuatu dengan lebih baik, tidak takut saat gagal, dan bangkit setelah mengalami kegagalan. Individu akan berpikir bahwa semua yang terjadi pada dirinya merupakan yang terbaik. Teori tersebut sesuai dengan hasil penelitian ini, yaitu mahasiswa yang sedang skripsi yang menjadi subjek penelitian ini menujukkan bahwa sebesar 58,71\% memiliki optimisme yang tinggi.

Busseri, Choma, dan Sadava (2009) mengemukakan bahwa optimisme ditandai dengan adanya harapan positif yang dirasakan individu dapat mengubah tanggapan negatif individu menjadi positif yang memengaruhi keadaan emosional individu tersebut. Hasil penelitian menunjukkan bahwa 91 subjek memiliki skor diatas nilai mean dan 64 subjek mempunyai skor dibawah nilai mean. Hasil tersebut menunjukkan bahwa subjek dalam penelitian ini dapat mengubah tanggapan negatif menjadi positif yang memengaruhi kedaan emosionalnya.

Hasil uji hipotesis memperlihatkan jika hubungan positif antara affiliative humor terhadap optimisme mahasiswa yang sedang skripsi tergolong sedang. Martin, Doris, Larsen, Gray, dan Weir (2003) mengemukakan bahwa individu yang memiliki affiliative humor yang tinggi cenderung menggunakan humor untuk menghibur dan memperkuat hubungan dengan individu lain, dengan cara mengatakan, menceritakan, dan melakukan hal-hal lucu dan spontan untuk menghibur orang lain, memfasilitasi hubungan, dan mengurangi ketegangan antar pribadi. Martin (2007) gaya affiliative humor berkaitan dengan kepuasan dalam hubungan, keceriaan, dan didominasi oleh emosi positif. Individu yang mempunyai skor affiliative humor yang tinggi, mampu membangun hubungan baik dengan individu lain yang didominasi emosi positif, sehingga dapat meningkatkan optimisme individu, namun individu yang memiliki skor affiliative humor yang rendah 
Philanthrophy Journal of Psychology

Vol 2 Nomor 1 (2018), 57-70

ISSN 2580-6076 (Print), ISSN 2580-8532 (Online)

tidak mampu membangun hubungan yang baik dengan individu lain.

Hasil uji hipotesis memperlihatkan jika hubungan positif antara self- enhancing humor terhadap optimisme mahasiswa yang sedang skripsi tergolong sangat rendah. Martin, Puhlik-Doris, Larsen, Gray, dan Weir (2003) mengemukakan bahwa self-enhancing humor mengacu pada kecenderungan individu merasa geli dan menertawakan peristiwa yang berbeda dalam hidup serta mempertahankan perspektif dalam menghadapi masalah. Individu yang memiliki skor self-enhancing humor yang tinggi dapat mengatasi masalah dengan cara menghibur diri sendiri, sehingga optimisme individu dapat meningkat. Individu yang mempunyai skor self-enhancing humor yang rendah tidak mampu untuk mempertahankan perspektif dalam menghadapi masalah yang berkaitan dengan skripsi.

Hasil uji hipotesis memperlihatkan jika hubungan negatif antara aggressive humor dengan optimisme mahasiswa yang sedang skripsi tergolong rendah. Martin, Puhlik-Doris, Larsen, Gray, dan Weir (2003) mengemukakan bahwa aggressive humor berkaitan dengan penggunaan humor yang menandakan suatu ancaman dari perkataan individu yang dapat memanipulasi diri individu. Gaya humor ini memiliki kecenderungan untuk mengekpresikan humor tanpa mempertimbangkan akibat yang dapat muncul pada individu lain. Individu yang mempunyai skor aggressive humor yang tinggi tidak mampu untuk mempertimbangkan akibat yang dapat dirasakan individu lain ketika mengekspresikan humor yang dimilikinya. Individu yang memiliki skor aggressive humor yang rendah mampu mengekspresikan humor dengan mempertimbangkan akibat dari perkataan yang akan diberikan kepada inidvidu lain, sehingga optimisme individu dapat meningkat.

Hasil uji hipotesis memperlihatkan jika hubungan negatif antara self-defeating humor dengan optimisme mahasiswa yang sedang skripsi tergolong sangat rendah. Martin, Puhlik-Doris, Larsen, Gray, dan Weir (2003) mengemukakan bahwa self-defeating humor berkaitan dengan tingkat kesejahteraan psikologis, kepuasan dalam hubungan, dan harga diri yang rendah. Individu dengan skor self- defeating humor yang tinggi tidak mampu untuk menghilangkan rasa tersisih dari individu lain, sedangkan individu dengan skor selfdefeating humor yang rendah mampu untuk mempertahankan kepuasan dalam berinteraksi dengan individu lain, sehingga optimisme individu dapat meningkat tanpa mengurangi maupun merugikan diri inidvidu dengan individu lain.

\section{Simpulan}

Berdasarkan penelitian dan pembahasan yang telah dikemukakan oleh peneliti sebelumnya, maka dapat disimpulkan bahwa terdapat hubungan positif yang sangat 
signifikan dan termasuk dalam kriteria koefisien korelasi yang sedang antara affiliative humor dengan optimisme mahasiswa yang sedang skripsi, artinya semakin tinggi affiliative humor maka semakin tinggi optimisme pada mahasiswa yang sedang skripsi. Hipotesisi 2 menunjukkan bahwa terdapat hubungan positif yang sangat signifikan dan termasuk dalam kriteria koefisien korelasi yang sangat rendah antara self-enhancing humor dengan optimisme mahasiswa yang sedang skripsi, artinya semakin tinggi self-enhancing humor maka semakin tinggi optimisme pada mahasiswa yang sedang skripsi. Hipotesis 3 disimpulkan bahwa terdapat hubungan negatif yang sangat signifikan dan termasuk dalam kriteria koefisien yang rendah antara aggressive humor dengan optimisme mahasiswa yang sedang skripsi, artinya semakin rendah aggressive humor maka semakin tinggi optimisme mahasiswa yang sedang skripsi. HIpotesis 4 dapat disimpulkan bahwa terdapat hubungan negatif yang sangat signifikan dan termasuk dalam kriteria koefisien yang sangat rendah antara self-defeating humor terhadap optimisme pada mahasiswa yang sedang skripsi, artinya semakin rendah self-defeating humor, maka semakin tinggi optimisme pada mahasiswa yang sedang skripsi.

Hasil penelitian yang telah dilakukan oleh peneliti dapat disarankan bagi individu yang berstatus mahasiswa yang sedang skripsi adalah optimisme yang rendah dapat meningkat dengan cara menggunakan gaya humor adaptif yaitu affiliative humor dan selfenhancing humor karena dapat meningkatkan optimisme yang memiliki peran penting dalam menentukan dan menggambarkan kemampuan diri individu dan hubungan sosial dengan individu lain. Bagi peneliti selanjutnya yang melakukan penelitian dengan topik sama diharapkan dapat memperluas ruang lingkup populasi penelitian, sehingga dapat menggeneralisasikan hasil penelitian lebih luas. Begitupula dengan proses penelitian sebaiknya memiliki jangka waktu yang panjang, sehingga subjek penelitian dapat lebih banyak ketika ada penambahan subjek.

\section{Daftar Pustaka}

Aisyah, S., Yuwono, S., \& Zuhri, S. (2015). Hubungan self-esteem dengan optimisme masa depan pada siswa santri program tahfids di pondok pesantren Al-Muayyad Surakarta dan Ibnu Abbas Klaten. Jurnal Indigenous, 13(2), 1-8.

Anhar, W. N. (2017). Hubungan antara optimisme dengan prokrastinasi pada mahasiswa yang menyusun skripsi. (Skripsi tidak diterbitkan). Makassar: Universitas Negeri Makassar.

Astuti, Y. D. (1999). Hubungan antara religiusitas dengan gaya penjelasan pada mahasiswa muslim. Psikologika, 4(8), 39-52.

Azwar, S. (2010). Metode penelitian. Yogyakarta: Pustaka Pelajar.

Azwar, S. (2015a). Penyusunan skala psikologi (Edisi 2). Yogyakarta: Pustaka Pelajar.

Azwar, S. (2015b). Reliabilitas dan validitas (Edisi 4). Yogyakarta: Pustaka Pelajar. 
Busseri, M. A., Choma, B. L., \& Sadava, S. W. (2009). "As good as it gets" or "The best is yet to come"? How optimists and pessimists view their past, present, and anticipated future life satisfaction. Journal of Personality and Individual Differences, 47(4), 352-356.

Carver, C. S., \& Scheier, M. F. (1993). On the power of positive thinking: The benefits of being optimistic. American Psychological Society, 2(1), 26-36.

Carver, C. S., Scheier, M. F., \& Segerstrom, S. C. (2010). Optimism. Clinical Psychology Review, 30, 879-889.

Carver, C. S., \& Connor-Smith, J. (2010). Personality and coping. Annual Review of Psychology, 61, 69-7041.

Chen, G. H., \& Martin, R. A. (2007a). A comparison of humor styles, coping humor, and psychological well-being between Chinese and Canadian university students. Humor: International Journal of Humor Research, 20(3), 215-234.

Chen, G. H., \& Martin, R. A. (2007b). A preliminary study of relationship between humor style and mental health. Psychological Science, 30, 219-223.

Chusniyah, T., \& Pitaloka, A. (2012). Analisis wacana pada media internet tentang optimisme dan harapan masa depan Indonesia. Journal Sains Psikologi, 2(2), 67-81.

Goleman, D. (2005). Kecerdasan Emosional. Jakarta: P.T Gramedia.

Ghufron, M. N., \& Risnawati, S. R. (2016). Teori-teori psikologi. Jogjakarta: Ar-Ruzz Media.

Guilford, J. P. (1956). Fundamental statistics in psychology and education. Tokyo: McGrawHill Book Company.

Hampes, W. P. (2005). Correlation between humor styles and loneliness. Psychological Report, 96, 747-750.

Kamus Pusat Bahasa. (2003). Kamus besar bahasa Indonesia. Jakarta: Balai Pustaka.

Kurniawan, S., Priyatama, A. N., \& Karyanta, N. A. (2015). Hubungan konsep diri dengan optimisme dalam menyelesaikan skripsi pada Mahasiswa Prodi Psikologi Fakultas Kedokteran UNS. Jurnal, 275-285.

Martin, R. A. (2004). Sense of humor and physical health: Theoretical issues, recent findings, and future directions. Humor, 17(1/2), 1-19.

Martin, R. A. (2007). The psychology of humor: An integrative approach. California: Elseiver.

Martin, R. A., \& Leftcourt, H. M. (1984). Situasional humor response quetionnare: Quantitative measure of sense of humor. Journal of Personality and Social Psychology, 47, 145-155.

Martin, R. A., Puhlik-Doris, P. P., Larsen, G., Gray, J., \& Weir, K. (2003). Individual differences in uses of humor and their relation to psychological well-being: Development of the humor styles questionnaire. Journal of Research in Personality, 37, 48-75.

Ningrum, D. W. (2011). Hubungan antara optimisme dan coping stress pada mahasiswa UEU yang sedang menyusun skripsi. Jurnal psikologi, 9(1), 41-47.

Nuzqia, F. (2017) hubungan antara gaya humor dengan tingkat kesepian pada anak tunggal. (Skripsi tidak diterbitkan. Makassar: Universitas Negeri Makassar.

Periantalo, J. (2015). Penyusunan skala psikologi: Asyik, mudah \& bermanfaat. Yogyakarta: Pustaka Pelajar.

Prawitasari, J. E. (2012). Psikologi terapan melintas batas disiplin ilmu. Jakarta: Erlangga.

Puspitasari, R. T. (2013). Adversity quotient dengan kecemasan mengerjakan skripsi pada mahasiswa. Jurnal online psikologi, 1(2), 299-310.

Scheier, M. F., \& Carver, C. S. (2002). Optimism. In C. R Snyder dan S. J. Lopez. Handbook of Positive Psychology. New York: Oxford University Press.

Seligman, M. E. P. (2006). Learned optimism: How to change your mind and your life. New York: Vintage books.

Siegel, S. (1997). Statistik nonparametrik untuk ilmu-ilmu sosial. Terjemahan oleh Zanzawi Sayuti \& Landung Simatupang. Jakarta: Gramedia Pustaka Utama.

Snyder, C. R., \& Lopez, S. (2002). Handbook of positive psychology. New York: Oxford University Press. 
Sowmya, S., Nizamudeen, Y., dan Magesh, P. (2015). A study on sense of humour and psychological wellbeing among young and middle adults. The International Journal of Humanities \& Social Studies, 3(4), 60-67.

Yolanda, K. A. (2016). Hubungan antara optimisme dengan pengambilan keputusan menikah pada mahasiswa strata I di Kota Makassar. (Skripsi tidak diterbitkan). Makassar: Universitas Negeri Makassar.

Yue, X. D., Hao, X., \& Goldman, G. L. (2010). Humor style, dispositional optimism, and mental health among undergraduates in Hong Kong and China. Journal of Psychology in Chinese Societies, 11(2), 81-96. 